\title{
Further Notes on the Evolution of Corporate Control and Institutional Investors: A Response to Niemonen
}

\author{
Harold R. Kerbo, California Polytechnic State University \\ L. Richard Della Fave, North Carolina State University
}

For many years, the debate over corporate ownership and control has been in a rut. At least since Berle and Mean's (1932) influential work, the debate has centered around the percentage of corporations that are owned and controlled by families vs. the percentage that are controlled by independent managers. Some researchers have devoted their careers to ferretting out new, hidden information which the most recent study has missed. Great significance has been given to a study which might find, for example, that 25 percent of the corporations are family-owned, rather than 38 percent. Jack Niemonen's critique of our article, of course, is in that tradition.

During this long debate, however, few social scientists have recognized that the subject matter has been changing. The simple categories of "family control" and "managerial control" are no longer adequate. Since 1932, we find the emergence of powerful institutional investors. As we noted in our work, over 40 percent of all corporate stock in the United States today is controlled by institutional investors. In some capitalist nations, this trend has gone even further. For example, in Japan, it is estimated that almost 70 percent of the corporate stock is controlled by institutional investors (Wallich and Wallich, 1976). (This trend in Japan was hastened by MacArthur's forced breakup of the old zaibatsu, the pre-World War II upper-class families that controlled major corporations (see Halliday, 1975; Reischauer, 1977).

Most important, our work is a beginning attempt to understand this new structure. As our article clearly indicated, we have many unanswered questions pertaining to institutional investors' place in the structure of corporate power. Predictably, however, Niemonen's critique has questioned the data indicating the reality of this new corporate structure. Thus, for the most part, we must respond on this level. In doing so, we take each of Niemonen's main points (the first three) in the order they were presented. We do this not because we agree with the order of their importance, but because we hope to make it easy for the reader to compare what we and Niemonen have written. 


\section{Primary Criticism}

(1) The first point seems rather trivial; perhaps he would have preferred "nearly new" evidence? The main point, however, is that the evidence is new to the debate over ownership and control. Seldom have institutional investors been mentioned in the literature; yet, they control almost half of U.S. stock. We examined some of the 1980 Corporate Data Exchange evidence, published by the Senate, before our article was in final form. These data in no way contradict that used in our article. For the questions we addressed, the 1978 publication was more useful in that it brought together data pertaining to the largest corporations of all types, as well as their stock-voting rights (not just ownership).

Niemonen may be suggesting that the 1976 data are old in the sense that much has changed since 1976. No doubt, there has been change in the exact percentage of stock controlled by specific investors in each corporation. But if he is suggesting that since 1976, there has been a significant increase in family ownership of the firms we examined, he is clearly wrong. The stock controlled by institutional investors shifts more than that held by individuals or families, and this must be recognized in new theories. But for major corporations in general, the only change has been a steady increase in institutional stock control.

(2) The second point, referring to our "sample," is clearly the most important and most confused.

First, the comment that the "sample" we used was "not statistically valid" makes no sense. Seldom are the studies of corporate ownership based on some kind of sampling procedure. These studies simply examine the largest 200 industrial corporations, or the largest 50 financial corporations, or something of this nature. The studies have then attemptd to explain the ownership and control patterns of the universe selected.

Second, Niemonen implied that our study was a replication of studies of the largest 200 or 500 industrial corporations, which it was not. The 122 corporations in the Senate publication Voting Rights in Major Corporations (with some minor exceptions, see U.S. Senate Committee on Governmental Affairs, 1978:7) included the largest corporations in each major type of corporation: 36 industrials, 23 transportation companies, 20 commercial banks, 20 utilities, 11 diversifiedfinancial and insurance companies, nine retailing companies, and three investment-advisory companies. A major point Niemonen has overlooked is that together, these 122 corporations account for 41 percent of all U.S. corporate stock (Kerbo and Della Fave, 1983:203). The data we used was "biased toward those firms whose major stockholders were financial institutions" simply because we examined data on the largest corporations. Even Domhoff (1983:63-66) agreed the largest corporations are less likely to be family-owned and -controlled. If we want to understand the nature of corporate power in the U.S., we must begin with these largest corporations. The group of large corporations included in the Senate publication provided us with unique data on the interrelations among and the ownership/control patterns of the largest corporations.

It is also important to note the value of including the largest financial and investment firms in the group of 122 corporations examined. Becaue the stock of the largest corporations is often dominated by these institutional investors we must examine their ownership and stock control patterns, as well. Family control of other corporations could be brought in via family control of these finan- 
cial firms (which we showed was unlikely). Thus, rather than using a "sample" of corporations which produced biased results, the group of corporations we examined was uniquely suited to provide very important, overlooked information on the ownership and control debate.

Finally, in this second point, we were criticized for neglecting the extent to which two or more families may pool their stock for corporate control. Again, with the corporations examined, we stress our original statement that such stock pooling would be quite limited, considering how few families are listed as owning at least .2 percent of the stock of any corporation. To make this point most strongly, we urge readers to scan the raw data listed in Voting Rights in Major Corporations (U.S. Senate Committee on Governmental Affairs:30-249). The pooling of stock by two or more families no doubt occurs; however, it is less likely to occur with the very large corporations, given the extent to which their stock is dominated by institutional investors.

Multiple-data sources may be used to locate more cases of family control of corporations smaller than most of those examined in our paper. But researchers must be cautious in using multiple-data sets of corporate ownership. It is tempting to look for data sets until you find the one you like or to take only the data you like from each data set.

(3) Niemonen concluded his third major point by stating, "The only valid conclusion sociologists can draw today is that we do not know whether family and individual investors play a significant or insignificant part in stock voting in the top 20 banks." Further, he stated that only "key insiders" know "who votes" the stock and "in whose interests." We devoted extensive discussion to the problem of discovering the interests behind stock votes ( $p$ 206-8, 216-17). This question requires much more study with unique research strategies to indicate the interests behind the proxy actions of institutional investors.

The other statements regarding who votes the stock proxies and the possibility of significant family investors in the top 20 banks suggest confusion over the operation of institutional investors. In the vast majority of cases, officers of the financial corporation vote the stock proxies from the corporate stock managed by institutional investors. In most cases, the institutional investors do not own the stock; rather, they usually have control over the stock votes (proxies) coming from the managed stock. The Corporate Data Exchange focused on voting rights held by investors (institutions or families), not simply stock ownership (U.S. Senate Committee on Governmental Affairs 1978:22). We have only used the data on voting rights.

As for family stock control in the top 20 banks, we again stress that in most cases, stock votes by families are insignificant. From the data supplied by the Corporate Data Exchange, the following is a list of all cases where a family or individual is listed as having one percent or more of the stock votes in any of the top 20 banks:

Chase Manhattan Corp.-Rockefeller family, 1.85 percent

Citicorp-Kirby family, 1.33 percent

First Bank Systems Inc.-Kirby family, 1.35 percent

Mellon National Corp.-Mellon family, 22.61 percent

Security Pacific Corp.-Keck family, 1.10 percent. There are two cases where a family has between .9 and one percent of the stock votes (in Chemical New 
York Corp. and Wells Fargo and Co.). If you reject the view that the trust department of a bank cannot have its stock-voting behavior influenced by major investors in the bank (the "Chinese Wall" argument) (p. 207-8), it can be argued there are a few other cases of family stock votes above one percent in the top 20 banks:

First Bank System Inc.-Mellon family, 1.31 percent

First Chicago Corp.-Rockefeller family, 1.83 percent

J. P. Morgan and Co.-Rockefeller family, 1.98 percent (this final case combines stock voted by Chase Manhattan Corp. and the Rockefeller family. Only in the case of Mellon National Corp. do we find clear family control (though we suggested why the Rockefeller family may have controlled Chase Manhattan in 1976-see p. 212).

\section{Secondary Criticisms}

Following his discussion of point three, Niemonen began a list of "certain other problems" with our article, which we assume he considred less important. For the most part, these other criticisms are redundant or involve other theorists he thought we should have discussed. We respond to most of these with short statements.

(1) It is difficult to believe anyone reading our article can say we had a "primary focus on interlocking directorates." We equally considered interlocking directorates and stock-voting rights.

(2) We are certainly aware of several studies "which have investigated the effects of corporate control on certain dependent variables, such as profit rates." In fact, a short discussion of some of these studies was cut from an early draft of our article. These studies have often been contradictory or have had negative results (for examples see James and Soref, 1981; Allen, 1981; Seider, 1977) because they have considered only family vs. managerial control, neglecting what we have called "intercorporate control" as another possible influence on the dependent variable (such as executive pay or profit rates).

(3) Of course, reciprocally held stock is rare among nonfinancial corporations. In the statement referred to by Niemonen-"the stock of these corporations is so heavily voted by each other" (p. 215)-we assumed no one would think we meant anything but financial institutions.

(4) We do not assume that "institutional ownership of stock must remain relatively stable over a number of years." As we clearly stated, we need to understand why there are shifts in institutional stock control (p. 217). The shifting patterns of stock control among the top financial institutions is one reason we suggested the concept of "intercorporate pluralism" (p. 213). The shifts in institutional stock control are a new reality with which theorists must come to grips. But to say there are shifts does not usually mean corporation $x$ at time $a$ is controlled by an institutional investor, then at time $b$ goes back to family control. More likely, it simply means that at time $b$, the coalition of institutional investors with stock control in corporation $x$ has been altered. 


\section{Conclusion}

We conclude with two more general comments related to Neimonen's critique.

First, wealthy families are still out there seeking profits as they always have. Many of these wealthy families continue to control certain corporations. However, with the largest corporations, family control is either becoming more scarce or it is maintained by means other than stock control. Even Niemonen's study of industrial corporations referred to finding 25 percent with family control. Using a 10-percent stock-control criteria, 11 percent of the 122 corporations in the data set we examined were under family control. While we are sure Niemonen would claim there are others under family control that could be identified with better data, the differences are not great. This is especially so, given the differing natures of the data sets.

Second, the study of corporate control must move from the type of ahistorical and ethnocentric theory and research apparently favored by Niemonen. The structure of corporate capitalism has been changing. We must understand the implications and outcomes of the change. As noted earlier, more than 40 percent of corporate stock is controlled by institutional investors today. At the current rate of growth, institutional stock control is projected to be 50 percent by 1986 , in contrast to only 25 percent in the mid-1950s (Allen, 1978). What happens when (and if) institutional stock control reaches 70 percent, as it has in Japan? To what degree are the economic differences between the U.S. and Japan related to differing levels of institutional stock control? Because we lack an adequate understanding of the effects of institutional stock control in the U.S. corporate structure, we cannot answer these questions with any confidence.

\section{REFERENCES}

Allen, Julius. 1978. "The exercise of voting rights by large institutional investors: a survey." Pp. 559-799 in U.S. Senate Committee on Governmental Affairs, Voting Rights in Major Corporations. Washington, D.C.: U.S. Government Printing Office.

Allen, Michael. 1981. "Power and privilege in the large corporation: corporate control and managerial compensation." American Journal of Sociology 86:1112-23.

Berle, Adolph, and Gardiner C. Means. 1932. The Modern Corporation and Private Property. New York: Macmillan.

Domhoff, G. William. 1983. Who Rules America Now? A View for the 80's. Englewood Cliffs, N.J.: Prentice-Hall.

Halliday, Jon. 1975. A Political History of Japanese Capitalism. New York Pentheon.

James, David, and Michael Soref. 1981. "Profit constraints on managerial autonomy: managerial theory and the unmaking of the corporation president." American Sociological Review 46:1-18.

$\rightarrow$ Kerbo, Harold R., and L. Richard Della Fave. 1983. "Corporate linkage and control of the corporate economy: new evidence and a reinterpretation." The Sociological Quarterly 24:201-18.

Reischauer, Edwin O. 1977. The Japanese. Cambridge, Mass.: Harvard University Press.

Seider, Maynard. 1977. "Corporate ownership, control and ideology: support for behavioral similarity." Sociology and Social Research 62:113-28.

United States Senate Committee on Governmental Affairs. 1978. Voting Rights in Major Corporations. Washington, D.C.: U.S. Government Printing Office.

Wallich, Henry C., and Mable I. Wallich. 1976. "Banking and finance." Pp. 249-316 in Hugh Patrick and Henry Rosovsky, eds., Asia's New Giant: How the Japanese Economy Works. Washington, D.C.: The Brookings Institution. 